Military Technical College

Kobry El-Kobbah, Cairo, Egypt

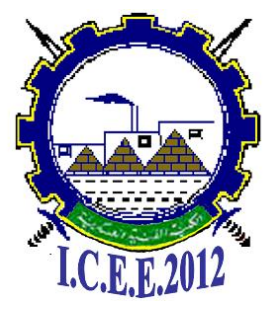

$6^{\text {th }}$ International Conference on

Chemical \& Environmental Engineering

29 -31 May, 2012.

CPTA-2

\title{
SYNTHESIES AND CHARACTERIZATION OF NEW POLY (URETHANE AMIDE) COMPOSITES FROM L-ASCORBIC ACID AS PROTECTIVE MATERIALS FOR PETROLEUM EQUIPMENT
}

\author{
Ossama M.Abo-Elenien* and K. M. Zohdy**
}

\begin{abstract}
Polyurethanes are among the most versatile polymers because of the wide range of monomers, particularly diols or polyols that can be utilized in their synthesis. This research focuses on the syntheses of poly(urethane amide) materials from L-ascorbic acid. The Lascorbic acid has been given to the use of as feedstock's for polymeric materials, because this tend to be inexpensive and available in large quantities. The new 2,3bis-((2aminoethylamino)ethyl) - 2,3,4,5,6 - pentahydroxy-2-enamide (AEAEPHA) resin has been synthesized from fused reaction of L- ascorbic acid with diethylenetriamine. The product AEAEPHA is purified and confirmed the structure by FT.IR, 1HNMR spectroscopy, and elemental analysis. The different 25,30,35,40,45,50 and 55 gm of AEAEPHA diluted with 10 $\mathrm{ml}$ solvent of dimethyl formamide, toluene and xylene, which are formulated with $5 \mathrm{gm}$ epoxy, $3 \mathrm{gm}$ from each $\mathrm{ZnO}_{2}, \mathrm{TiO}_{2}$, and $\mathrm{CaCO}_{3}, 2 \mathrm{gm}$ Al-silicate ,5gm Talc and $10 \mathrm{gm} \mathrm{Zn}$ dust. The different concentration 5, 10, 15 and $20 \mathrm{gm}$ of curing agent toluene diisocyanate (TDI) is used as curing agent with each formulation. These formulations are applied on the prepared surface of mild steel specimens of petroleum equipment by brushed method to form a poly(urethane amide) epoxy films. The physical, mechanical, chemical and corrosion properties of these films are discussed and promised results are indicated that the possibility of using these coating formulations in the protection of petroleum and various industrials equipment.
\end{abstract}

Key words: - poly (urethane-amide), films characterization, physical, mechanical, chemical and corrosion, mild steel.

* Egyptian Petroleum Research Institute (EPRI),Nasr City, Cairo, Egypt.

** Higher Technological Institute (HTI), Tenth of Ramadan City, Egypt

E mail drossamaa13@yahoo.co 


\section{Introduction}

The most petoleum, petrochemials, gases and different industries equipment are depend on the carbon steel. The carbon steel alloys are affected (corroded) quickly when subjected to both chemically and physically environmental corrosion [1-10].

The depletion of world oil pool, rising price of crude oil and increased environmental concernce are pressurizing the scientests for the use of renewable natural resources in different fields of applications as they are eco-friendly and cost effective materials. In this regard, vegetable oils have a number of excellent properties, which could be utilized in production for variable polymeric materials such as alkyd, epoxy, polyesteramide, polyurethane, etc. in addition to many applications in other fields[2-16]. The seeds like castor, linseed, cashewnut, sobean, etc. have been successfully utilized to syntheize polyurethane resin[ 5-9, 12-17].

Advances materials performance often require the development of composite system, of which protected materials are both one and mixture (formula) form. The corrosion resistance of components can be greatly increased by protective painting and this is a growing industry of considerable economic importance. Petroleum, petrochemical and other industeries are subjected to high temperature and enviromental corrosion, as well as highly beneficial painting have been developed.

Factors that must be taken into account include substrate compatibility, adhesion, porosity, the possibility of repair or repainting, inter diffusion, the effect of thermal cycling, salt spray, resistance to petroleum and petrochemical products, and corrosion protection as well as cost.The alternative systems emphasises the necessity for the painting (protective) of the surface of substrate[1-17]

In this work, the new 2,3bis-((2-aminoethylamino)ethyl) - 2,3,4,5,6 - pentahydroxy-2enamide (AEAEPHA) resin has been synthesized. The AEAEPHA was formulated with inorganic additives and epoxy resin which were cured with toluene di-isocyanate (TDI). These formulations were applied on the prepared surface of mild steel specimens by brushed method to form a polyurethane amide epoxy films, characterization and performance the physical, mechanical, chemical and corrosion properties of these films based on poly(urethane amide) resin as protective material.

\section{Experimental Work}

\subsection{Materials}

The all materials were supplied from aldrich company in commerical form witout any purification.

\subsection{Preparation of AEAEPHA resin}

The preparation of amide compound AEAEPHA was carried out in free solvent by reaction one mole of L-Ascorbic acid (176 g) with one mole of diethylenetriamine ( $103 \mathrm{~g}$ ) by fusion where temperature was raising stepwise until to $170-190{ }^{\circ} \mathrm{C}$ (scheme 1$)$. Then, the product AEAEPHA, was purified by vacuum distillation and confirmed by (FT-IR), $\left({ }^{1} \mathrm{HNMR}\right)$ 
spectroscopy and elementary analysis.<smiles>O=C1OC([C@@H](O)CO)C(O)=C1O</smiles>

L-ascorbic acid<smiles>[CH2-]CNCCNCC[NH3+]</smiles>

Diethylenetriamine<smiles>NCCNCCNC(=O)/C(O)=C(\O)C(O)C(O)CO</smiles>

\section{Scheme 1}

2.3 Characteristic properties of the synthesized AEAEPHA compound.

\subsubsection{Infra-red analysis ( FT-IR).}

The IR spectra of the synthesized AEAEPHA compound was measured by using FT-IR Spectrometer model type Mattson-Infinity series bench top 961. The

wave number and inten-sities of IR bands of the different types of the function groups were determined in a range of $4000-500 \mathrm{~cm}^{-1}$.

\subsubsection{Nuclear Magnetic Resonance ${ }^{1}$ HNMR.}

The ${ }^{1}$ HNMR of the synthesized AEAEPHA compounds were measured by $200 \mathrm{MHZ}$ spectrometer Gemini-200. The solution for ${ }^{1} \mathrm{HNMR}$ analysis was prepared by dissolving the AEAEPHA compound in dimethyl sulfoxide.

\subsubsection{Elementary analysis}

Table (1): The elemental analyses for AEAEPHA

\begin{tabular}{|ll|l|}
\hline Parameter & Resin (AEAEPHA) \\
\hline Molecular Weight & 279.29 \\
\hline Molecular Formula & $\mathrm{C}_{10} \mathrm{H}_{21} \mathrm{~N}_{3} \mathrm{O}_{6}$ \\
\hline $\mathrm{C} \%$ & Calculated & 43.01 \\
& Found & 43.07 \\
\hline $\mathrm{H} \%$ & Calculated & 7.57 \\
& Found & 7.53 \\
\hline $\mathrm{N} \%$ & Calculated & 15.05 \\
& Found & 15.09 \\
\hline $\mathrm{Si} \%$ & Calculated & -- \\
& Found & -- \\
\hline
\end{tabular}




\subsection{Preparation of the painting formula.}

The chemical composition of the painting formula $E_{1}$ to $E_{7}$ from the synthetic AEAEPHA was given in Table (2).

\subsection{Preparation of the surface of metal specimens.}

The unused mild steel specimens were provided from Badr Eldeen petroleum company. The specimens were cut as regular edged cuboids with dimensions 8,15,0.1 cm. Each specimen was cleaned, polished with 600,400,150 emery paper, rinsed with distilled water, degreased with acetone, weighed and finally stored under vacuum after wrapping with adhesive paper.

\subsection{The optimization steps to form the polyurethane amide epoxy coating.}

The optimization steps were generally, carried out under water static air at ambient pressure and temperature within a selection formula from $E_{1}$ to $E_{7}$. A set of specimens coated with each formula of poly(urethane amide) epoxy and were cured with different concentration 5, 10, 15 and $20 \mathrm{gm}$ of curing agent TDI until complete cured. The forming films over the surface of specimens were examined by measuring the wet film thickness (WFT), dry film thickness (DFT), adhesion, impact, bending test,.... Etc. Having determined the optimum condition with the selected formula, at which the formation of the best coating was achieved in steps. The optimum concentration of TDI was kept constant through the optimization procedure.

\subsection{The characterization techniques.}

The physical, mechanical and chemical properties of the formed coatings were carried out through the following characterization techniques:-

\subsubsection{Physical properties}

2.7.1.1 Wet film thickness(WFT). The wet film thickness (WFT) of coating was measured according to ASTM (D-1212-91). The WFT gauge type elcometer is used for assessing the thickness of freshly applied coating films for all formulations $E_{1}$ to $E_{7}$ at ambient temperature, the obtained results were recorded after coating immediately.

\subsubsection{Dry film thickness (DFT).}

The Dry film thickness (DFT) of coating was measured according to ASTM. (D-1186 and 1005). The DFT of the formed films for all formulation $E_{1}$ to $E_{7}$ after cured at ambient temperature were measured by using Posit-Ector, model 6000-FT2, coating thickness with probe gauge $6000-\mathrm{FT} 2$. The average film thickness is computed from five reading, one at the middle and the others at the four corners of regular cubed specimen's surface. The obtained results were recorded after curing and tabulated.

\subsubsection{Adhesiontest.}

This technique according to ASTM(D 3359) and Din 30670.

Peel test. These test methods were covered procedures for assessing the adhesion of coating films to metallic substrates surface by two methods:-

1-An X-cut was made in the film to the substrate, pressure-sensitive tape was applied over the cut and then removed, and the adhesion is assessed qualitatively on the 0 to 5 scale.

2-A lattice patterns with either six or eleven cuts in each direction was made in the film to the substrate, pressure-sensitive tape was applied over the lattice and then removed, the adhesion was evaluated by comparison with illustrations. 
2.7.1.4 Burnishing test. It is carried out according to BS-6670 part 5. An area of not more than $6 \mathrm{~cm}^{2}$ of the significant surface was select, and rubbed rapidly and firmly for $15 \mathrm{sec}$. with a suitable burnishing tool. A sufficient pressure was applied to burnish the coating metal every stroke, but not as agreed as cut the coating, the specimens were examined for signs of blistering of the coating under an illuminated viewer.

2.7.1.5 Thermal cycling test. It is carried out according to BS-6670 part 5. The sample was heated gradually from $50{ }^{\circ} \mathrm{C}$ to $400{ }^{\circ} \mathrm{C}$ increasing by $25{ }^{\circ} \mathrm{C}$ for approximately $6 \mathrm{hrs}$. The coating was examined for signs of blistering or detachment under a magnification viewer.

2.7.1.6 Pinhole test. It is carried out according to ASTM (D-5162-91). The pinhole of the formed films of poly(urethane amide) epoxy on the surface of mild steel specimens were measured by holiday detector model Poro test DC through the following equation:

\subsubsection{Mechanical properties}

$$
\mathrm{V}=5 \times \mathrm{xFT}
$$

2.7.2.1 Bending test. It is carried out according to ASTM (D-522-93A). This test was covered the determination of the resistance to cracking of attached organic coating of the formed films on the surfaces of specimens, which were measured by using bending tester 5-35 mm Richmond Road King Stone type $\mathrm{KT}_{2}$ 5BQ consisting of a metal cone, a rotating panel bending arm, and panel clamps all mounted on a metal base. This cone, smooth steel, 8 in. $(200 \mathrm{~mm})$ in length with a diameter of $1 / 8 \mathrm{in} .(3 \mathrm{~mm})$ at one end and a diameter of $1 / 2 \mathrm{in} .(28$ $\mathrm{mm})$ at other end. The obtained results were recorded and tabulated.

2.7.2.2 Pencil hardness test of polyamide coating. It is carried out according to ASTM(D3363-05). The hardness of the formed coating on the specimen's surface was measured by using hardness pin test rod model 318. The hardness of the formed coating was measured at fine points, one at the middle of specimen and others at the four corners. The obtained results were recorded and tabulated.

2.7.2.3 Impact test. This techniques is carried out according to ASTM (D-2794-93) and (G1488). The deformation of the formed films on the surface of specimens were determined by using Richmond Road King stone type $\mathrm{KT}_{2} 5 \mathrm{BQ}$. Install the punch having the head diameter specified, the test specimen was placed in the apparatus with the coated side up. The specimen was flat against the base support and the indenter was in contact with the tap surface of the specimen. The weight was placed at the zero mark and dropped suddenly on the coated surface of the specimens. The test specimen is removed from the apparatus and the impact area was observed for cracking the coating. The test was repeated five times at each of three heights and the impacted area examined by using magnification power. The obtained results were recorded and tabulated.

\subsubsection{Chemical properties}

\subsubsection{Evaluation the effect of organic solvent.}

It is carried out according to ASTM (G-44). The stability of the formed films from poly(urethane amide) epoxy was examined. The test was carried out by immersion of dry coating specimens in a mixture of benzene, toluene and xylene for period time $6,12,24,48$ and 72 days respectively at ambient temperature. 


\subsubsection{Effect of methyl ethyl ketone (MEK).}

It is carried out according to ASTM (D-4752 and 740-94). Studies the effect of MEK on the stability and compatibility of the formed dry films on the surface of mild steel specimen are carried out by the scratching of the films to 30-50 types by wetting cotton. The observed results were recorded and tabulated.

\subsubsection{Evaluation of the formed films as a corrosion protection methods.}

These are carried out according to ASTM (D-468, 610, 3730-94 and G-31). The coating specimens were immersed in the different aggressive media as following:-

\subsection{Synthetic sea water (S.W) $5 \% \mathrm{NaCl}$ at ambient temperature.}

The test was carried out on the dry films formed on the surface of mild steel specimens 72 days. The visual inspection of the coating surface were investigated, the degree of rusting were computed and evaluated.

\subsubsection{2 $\mathrm{H}_{2} \mathrm{SO}_{4}$ concentration $10 \%$ at ambient temperature,}

The test was carried out on the dry films formed on the surface of mild steel specimens 50 days as period time. The visual inspection of the coating surface were investigated, the degree of rusting were computed and evaluated.

\section{Results And Discussion.}

\subsection{Confirmation of the prepared compound:}

The chemical structure of the prepared AEAEPHA compound (Schemes 1) was characterized via:

\subsubsection{Infrared technique FT-IR}

Fig (1) illustrate the FT-IR spectrum for Binder AEAEPHA, the characteristic bands at 1024 and $3400 \mathrm{~cm}^{-1}$ represent the band of primary alcohol $-\mathrm{CH}_{2}-\mathrm{CH}_{2}-\mathrm{OH}$, the bands at 1389 and $3361 \mathrm{~cm}^{-1}$ represent the band of tertiary alcohol $-\mathrm{C}-\mathrm{OH}$, the bands at 922 and $1099 \mathrm{~cm}^{-1}$ represent the band of primary amine $\mathrm{H}_{2} \mathrm{~N}_{-} \mathrm{CH}_{2}$ - and the bands at 1770 and $3324 \mathrm{~cm}^{-1}$ represent the band of mono substitute amide -CO-NH-R.

\subsubsection{Nuclear Magnetic Resonance ${ }^{1}$ HNHR}

Fig (2) illustrate the ${ }^{1} \mathrm{HNMR}$ spectra for binder AEAEPHA ${ }^{1} \mathrm{HNMR}$ and was represented the characteristic bands of primary alkane group at 2.5-3.2 ppm, Amino group At 3.5 PPM and $\mathrm{OH}$ group appear at $3.9 \mathrm{ppm}$ and carbonyl group at $8 \mathrm{ppm}$.

\subsection{Chemical composition of the painting formula $E_{1}$ to $E_{7}$.}

The chemical composition of the painting formula $E_{1}$ to $E_{7}$ for the synthetic binder AEAEPHA were given in Table (2). 
Table -2 Chemical composition of Formula for binder AEAEPHA.

\begin{tabular}{|l|l|l|l|l|l|l|l|}
\hline \multicolumn{1}{r|}{ Formula } & $\mathrm{E}_{1}$ & $\mathrm{E}_{2}$ & $\mathrm{E}_{3}$ & $\mathrm{E}_{4}$ & $\mathrm{E}_{5}$ & $\mathrm{E}_{6}$ & $\mathrm{E}_{7}$ \\
\hline $\begin{array}{l}\text { Materials } \\
\text { resin }\end{array}$ & 25 & 30 & 35 & 40 & 45 & 50 & 55 \\
\hline $\mathrm{TiO}_{2}$ & 5 & 5 & 5 & 5 & 5 & 5 & 5 \\
\hline $\mathrm{ZnO}_{2}$ & 3 & 3 & 3 & 3 & 3 & 3 & 3 \\
\hline $\mathrm{CaCO}_{3}$ & 3 & 3 & 3 & 3 & 3 & 3 & 3 \\
\hline $\mathrm{Al}$-silicate & 2 & 2 & 2 & 2 & 2 & 2 & 2 \\
\hline Talc & 5 & 5 & 5 & 5 & 5 & 5 & 5 \\
\hline $\mathrm{Zn}$ Dust & 10 & 10 & 10 & 10 & 10 & 10 & 10 \\
\hline Epoxy & 5 & 5 & 5 & 5 & 5 & 5 & 5 \\
\hline Solvent & 10 & 10 & 10 & 10 & 10 & 10 & 10 \\
\hline $\begin{array}{l}\text { Curing agent } \\
\text { TDI }\end{array}$ & 5 & 5 & 5 & 5 & 5 & 5 & 5 \\
& 10 & 10 & 10 & 10 & 10 & 10 & 10 \\
& 15 & 15 & 15 & 15 & 15 & 15 & 15 \\
& 20 & 20 & 20 & 20 & 20 & 20 & 20 \\
\hline
\end{tabular}

The binder AEAEPHA at different quantity 25, 30, 35, 40, 45, 50 \& 55 gm were mixed with 5 gm Epoxy and blended with inorganic additives at $0.5 \mathrm{gm}$ for each $\mathrm{TiO}_{2}$ and $3 \mathrm{gm}$ of $\mathrm{ZnO}_{2}$, $\mathrm{CaCO}_{3}, 2 \mathrm{gm}$ of Al-silicate, $5 \mathrm{gm}$ Talc and $10 \mathrm{gm} \mathrm{Zn}$ dust, as well as blended organic, 10gm solvents.

\subsection{Studies the optimization of curing agent.}

Tables (3) illustrate the optimum quantity of the curing agent of TDI for each formula of $E_{1}$ $E_{7}$. The touch dry time was the main factor determine the optimium of TDI concentration for drying the painting films on the surface of specimens. The drying (curing time) for each formula of $E_{1}-E_{7}$ were given in Table (3), since the different concentration of TDI are 5, 10, 15 and $20 \mathrm{gm}$ were studied for each formula of $E_{1}-E_{7}$.

Table -3 Data of the optimum condition for the curing agent against touch dry time for each formula at ambient condition.

\begin{tabular}{|c|c|c|c|c|c|c|c|}
\hline $\begin{array}{c}\text { The curing } \\
\text { agent (TDI) } \\
\text { conc.(gm) }\end{array}$ & \multicolumn{7}{|c|}{ Touch dry time for each formed films from } \\
the formula (hr) \\
\cline { 2 - 9 } & $\mathrm{E}_{1}$ & $\mathrm{E}_{2}$ & $\mathrm{E}_{3}$ & $\mathrm{E}_{4}$ & $\mathrm{E}_{5}$ & $\mathrm{E}_{6}$ & $\mathrm{E}_{7}$ \\
\hline $5 \mathrm{gm}$ & 8 & 7 & 5 & 5 & 4 & 4 & 4 \\
\hline $10 \mathrm{gm}$ & 7 & 6.5 & 4.5 & 4.5 & 4 & 3.5 & 3.5 \\
\hline $15 \mathrm{gm}$ & 4 & 4 & 3 & 2 & 2 & 2 & 1.5 \\
\hline $20 \mathrm{gm}$ & 5 & 4 & 4 & 1.5 & 1 & 0.5 & 0.5 \\
\hline
\end{tabular}

From the optimization studies of the curing agent TDI concentrat, it was observed that the promissing touch dry time was given good results at $15 \mathrm{gm}$ of TDI. These results were illusterated that the touch dry time were affected by the increasing in quantity of AEAEPHA resin. So that, at increased of AEAEPHA decreasing the touche curing time. 


\subsection{Physical and mechanical properties of the formed films.}

\subsubsection{Physical properties.}

\subsubsection{Visual inspection}

The visual inspection for the formed films from formula $E_{1}$ to $E_{7}$ were carried out. The data of application painting on the surface of specimens were visually inspected directly, and it was observed that, the formation films from formula $E_{1}$ and $E_{2}$ were seald, while the formation films from formula $E_{3}$ to $E_{7}$ were not seald, on the other hand the all visual inspection phenomena were given excellent results as, sagging, fish eyes, shrinkable and / or coagulation, and also, the homogeneity and smoothes during and after complete curing time for formula $\mathrm{E}_{3}-\mathrm{E}_{7}$ were excellent promissed results.

The forming dry films during and after curing on the surface of specimens were showed as one layer compatible with each other, compact and adhesion as well as stable on the surface of specimens.

\subsubsection{Calculating of the wet and dry films formed on mild steel specimens surface.}

The calculating data of the wet and dry films on the surface of specimens from formula $\mathrm{E}_{1}-\mathrm{E}_{7}$ were recorded in Table (4). From these data, one illusterats that the wetting and drying films were depended on the resin concentration. From these results the normalized weight of wetting films are matched with these of drying films formed on surface of specimens. Also the normalized weight per unit area data for wetting and drying films confirm the optimization condition of TDI with binder. Also, the films thickness were increased by increasing the AEAEPHA concentration.

\subsubsection{Measuring wet and dry film thickness data.}

The measuring data of formation wet and dry films thickness from formula $E_{1}-E_{7}$ were given in Table (5), respectively. These data were observed that the film thickness were increased by increasing the AEAEPHA resin concentration.

\subsubsection{Adhesive forcing of the formed dry films with the surface of specimens.}

The adhesive forces data between the formed films and surface of specimens were given in table (6). From these data, we observed that the adhesive forcing of the formed films were increased byincreasing the resin concentration. And we illustrated that the additives of inorganic filler like $\mathrm{ZnO}_{2}, \mathrm{TiO}_{2}, \mathrm{Zn}$ dust and $\mathrm{Al}$ silicat were effected on the adhesion forces. These pheomena were indicated that the increasing concentration of AEAEPHA material, was improved the adhesion properties of formed dry films for formula $E_{2}-E_{7}$. From these results we should be concluded that the formation films from these formula were valied to application on the surface of petroleum and industries equipment.

\subsubsection{Holiday detection of the formed dry films.}

The data of holiday (pinhole) detection of the formed dry films from formula $E_{1}-E_{7}$ were given in Table (6). The measuring voltage of pinhole depended on the thickness of the films according to the following equation:- Measuring voltages $=5 \mathrm{x}$ DFT

Since the dry film thickness for $E_{1}-E_{7}$ are $80 \pm 5 \mu \mathrm{m}$, so that, the measuring voltage for the formed dry film are 400 volt for $E_{1}-E_{7}$, respectively. The main measuring results according to the above voltage value were failure of the $E_{1}-E_{2}$ and passed for the $E_{3}-E_{7}$, respectively. From these data we should be concluded that, the protection value were depend on the concentration of resin, and were indicated on the good compatibility of these fillers with the polyurethane amid films. So that, we should be recommended that these formula should be applied for protection of mild steel surfaces of equipment. 


\subsubsection{Thermal cycling test for the formed dry films.}

The data of the thermal cycling test for the formed dry films from the formula $E_{1}-E_{7}$ were showed in Table (7). The effective degree of temperature ranged from 50 to $400{ }^{\circ} \mathrm{C}$ by increasing $25{ }^{\circ} \mathrm{C}$ intervals. From the observation data as in Table (8) showed that the formation dry films of formula $\mathrm{E}_{1}$ was failure at $275^{\circ} \mathrm{C}$. On the other hand the formation dry films from formula $\mathrm{E}_{2}, \mathrm{E}_{3}$ were failure at $325^{\circ} \mathrm{C}$, and $\mathrm{E}_{4}$ was failure at $350{ }^{\circ} \mathrm{C}$. While the formation dry films from formula $\mathrm{E}_{5}-\mathrm{E}_{7}$ were thermal stable untile $400^{\circ} \mathrm{C}$. So that, we were observed that, the stability temperature of formation dry films were increased by increasing the AEAEPHA compound. Finaly, we should be recommeded that, the formed dry films from formula $E_{2}-E_{7}$ were valied for protection of mild steel surfaces of petroleum and industries equipment at temperature between $300-400{ }^{\circ} \mathrm{C}$. 
Table-4 The calculating data for each formed wet and dry films from $E_{1}-E_{7}$ at ambient condition.

\begin{tabular}{|c|c|c|c|c|c|c|c|c|c|c|}
\hline $\begin{array}{l}\text { Complete } \\
\text { Dry time } \\
\text { (days) }\end{array}$ & $\begin{array}{l}\text { Touch } \\
\text { dry time } \\
\quad(\mathrm{hr})\end{array}$ & $\begin{array}{c}\text { Relative } \\
\text { humidity } \\
\text { ( R.H) }\end{array}$ & $\begin{array}{l}\text { Curing } \\
\text { Temp. } \\
{ }^{\circ} \mathrm{C}\end{array}$ & $\begin{array}{l}\text { Normalized } \\
\text { Weight } \\
\text { dry films } \\
\text { Per unit area } \\
\left(\mathrm{g} / \mathrm{cm}^{2}\right) \\
\end{array}$ & $\begin{array}{l}\text { Weight of } \\
\text { dry films } \\
\quad(\mathrm{g})\end{array}$ & $\begin{array}{l}\text { Normalized } \\
\text { Weight of } \\
\text { wet films } \\
\text { Per unit area } \\
\left(\mathrm{g} / \mathrm{cm}^{2}\right)\end{array}$ & $\begin{array}{l}\text { Weight of } \\
\text { Wet films } \\
\quad(\mathrm{g})\end{array}$ & $\begin{array}{l}\text { Specimen } \\
\text { Area of one } \\
\text { surface } \\
\left(\mathrm{cm}^{2}\right)\end{array}$ & $\begin{array}{l}\text { Weight of } \\
\text { cleaning } \\
\text { Specimens } \\
\quad(\mathrm{g})\end{array}$ & $\mathrm{S}$ \\
\hline \multirow{7}{*}{$3-4$} & 4 & \multirow{7}{*}{$>50$} & \multirow{7}{*}{ 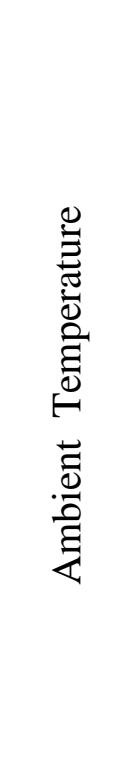 } & 0.021898 & 3.4081 & 0.023476 & 3.6536 & 155.6325 & 71.2658 & $\mathrm{E}_{1}$ \\
\hline & 4 & & & 0.023195 & 3.6107 & 0.024516 & 4.8058 & 155.2356 & 72.0056 & $\mathrm{E}_{2}$ \\
\hline & 3 & & & 0.024597 & 3.8019 & 0.027462 & 4.2625 & 155.2145 & 71.9658 & $\mathrm{E}_{3}$ \\
\hline & 2 & & & 0.025282 & 3.9611 & 0.030072 & 4.6759 & 155.4879 & 71.9985 & $\mathrm{E}_{4}$ \\
\hline & 2 & & & 0.026093 & 4.0564 & 0.031947 & 4.9665 & 155.4587 & 72.0682 & $\mathrm{E}_{5}$ \\
\hline & 2 & & & 0.027423 & 4.2566 & 0.032907 & 5.0785 & 155.2365 & 72.0055 & $\mathrm{E}_{6}$ \\
\hline & 1.5 & & & 0.028063 & 4.3564 & 0.034667 & 5.3815 & 155.2348 & 71.9862 & $\mathrm{E}_{7}$ \\
\hline
\end{tabular}


Table - 5 Measuring wet and dry films thickness data for formed films.

\begin{tabular}{|c|c|c|c|c|}
\hline $\begin{array}{c}\text { Average } \\
(\mathrm{DFT}) \mu \mathrm{m}\end{array}$ & $\begin{array}{c}\text { Dry film } \\
\text { thickness } \\
(\mathrm{DFT}) \mu \mathrm{m}\end{array}$ & $\begin{array}{c}\text { Average } \\
\text { (WFT) } \\
\text { Mm }\end{array}$ & $\begin{array}{c}\text { Wet film } \\
\text { thickness } \\
(\text { WFT }) \mu \mathrm{m}\end{array}$ & Formula \\
\hline & 80 & & 120 & $\mathrm{E}_{1}$ \\
\hline $85 \pm 5$ & 81 & & 123 & $\mathrm{E}_{2}$ \\
\hline & 83 & $125 \pm 5$ & 125 & $\mathrm{E}_{3}$ \\
\hline & 85 & & 128 & $\mathrm{E}_{4}$ \\
\hline & 87 & & 130 & $\mathrm{E}_{5}$ \\
\hline & 89 & & 133 & $\mathrm{E}_{6}$ \\
\hline & 91 & & 136 & $\mathrm{E}_{7}$ \\
\hline
\end{tabular}

Table-6 The physical and mechanical properties of the dry films formed from $E_{1}-E_{7}$

\begin{tabular}{|c|c|c|c|c|c|c|c|}
\hline Impact & Hardness & Adhesion & Pinhole & Bending & DFT & WFT & Symbol \\
\hline Failure & $\mathrm{HB}$ & Failure & Failure & Failure & 80 & 120 & $\mathrm{E}_{1}$ \\
\hline Failure & $\mathrm{H}$ & Pass & Failure & Failure & 81 & 123 & $\mathrm{E}_{2}$ \\
\hline Pass & $2 \mathrm{H}$ & Pass & Pass & Pass & 83 & 125 & $\mathrm{E}_{3}$ \\
\hline Pass & $5 \mathrm{H}$ & Pass & Pass & Pass & 85 & 128 & $\mathrm{E}_{4}$ \\
\hline Pass & $6 \mathrm{H}$ & Pass & Pass & Pass & 87 & 130 & $\mathrm{E}_{5}$ \\
\hline Pass & $8 \mathrm{H}$ & Pass & Pass & Pass & 89 & 133 & $\mathrm{E}_{6}$ \\
\hline Pass & $10 \mathrm{H}$ & Pass & Pass & Pass & 91 & 136 & $\mathrm{E}_{7}$ \\
\hline
\end{tabular}

\subsubsection{Volatile of organic compounds VOC.}

Table (7) illusterats the volatile of organic compounds from the paints after curing were either estimated from the formulations and / or the using of organic solvent dimethylformamide, toluene and xylene as well as binder. However, the mixture of blended solvents were evaporated after drying of the paints on the surface of mild steel specimens at ambient condition and during the curing and / or drying process were carried out.

Table-7 Thermal cycling test (stability) of the dry films formed from formula $E_{1}-E_{7}$.

\begin{tabular}{|c|c|c|c|c|c|c|c|c|}
\hline \multicolumn{7}{|c|}{ Weight losses for each formed films $\times 10^{-4}$} & \multirow{2}{*}{$\begin{array}{c}\text { Period } \\
\text { Time }\end{array}$} & \multirow{2}{*}{ Temp. ${ }^{\circ} \mathrm{C}$} \\
\hline $\mathrm{E}_{7}$ & $\mathrm{E}_{6}$ & $\mathrm{E}_{5}$ & $\mathrm{E}_{4}$ & $\mathrm{E}_{3}$ & $\mathrm{E}_{2}$ & $\mathrm{E}_{1}$ & & \\
\hline 0.5 & 0.5 & 0.6 & 0.8 & 1.1 & 1.4 & 1.8 & \multirow{15}{*}{$6 \mathrm{hrs}$} & 50 \\
\hline 0.2 & 0.3 & 0.4 & 0.5 & 0.8 & 1.1 & 1.6 & & 75 \\
\hline 0.0 & 0.0 & 0.1 & 0.2 & 0.5 & 0.8 & 1.4 & & 100 \\
\hline 0.0 & 0.0 & 0.0 & 0.0 & 0.2 & 0.5 & 0.7 & & 125 \\
\hline 0.0 & 0.0 & 0.0 & 0.0 & 0.0 & 0.0 & 0.0 & & 150 \\
\hline 0.0 & 0.0 & 0.0 & 0.0 & 0.0 & 0.0 & 0.0 & & 175 \\
\hline 0.0 & 0.0 & 0.0 & 0.0 & 0.0 & 0.0 & 0.0 & & 200 \\
\hline 0.0 & 0.0 & 0.0 & 0.0 & 0.0 & 0.0 & 0.0 & & 225 \\
\hline 0.0 & 0.0 & 0.0 & 0.0 & 0.0 & 0.0 & 0.0 & & 250 \\
\hline 0.0 & 0.0 & 0.0 & 0.0 & 0.0 & 0.0 & Failure & & 275 \\
\hline 0.0 & 0.0 & 0.0 & 0.0 & 0.0 & 0.0 & Failure & & 300 \\
\hline 0.0 & 0.0 & 0.0 & 0.0 & \multicolumn{3}{|c|}{ Failure } & & 325 \\
\hline 0.0 & 0.0 & 0.0 & \multicolumn{4}{|c|}{ Failure } & & 350 \\
\hline 0.0 & 0.0 & 0.0 & \multicolumn{4}{|c|}{ Failure } & & 375 \\
\hline 0.0 & 0.0 & 0.0 & \multicolumn{4}{|c|}{ Failure } & & 400 \\
\hline
\end{tabular}


Also the weight of the formed films after every step of the thermal effected were decreased until the weight established, this phenomena were illusterated from the physical properties as all. Where the emission of the organic compounds (weight lossess ) during the both curing process and the thermal test were happened.

\subsection{Mechanical Properties.}

\subsubsection{Hardness data}

Table (6) illusterates that the data of the hardness values were increased with increasing the concentration of AEAEPHA compound. These data were indicated that, the promising validity of the formed dry films from formula $E_{1}-E_{7}$. These phenomena were cleared at formula $\mathrm{E}_{3}-\mathrm{E}_{7}$.

3.5.2 Impact data. This technique was applied to evaluate the validity of the formed dry films from formula $E_{1}-E_{7}$. The observed data were given in Table (6). These data were showed that, the formed dry film from formula $E_{1}$ and $E_{2}$ invalid while valid from $E_{3}-E_{7}$. These results were depended on the formation homogenity and compitability of formation poly(urethane amide) films, physical and chemical bonds between the films and the inorganic filler/pigment additives, and some traces of hydroxylgroups on the surface of Al silicat were reacted with some isocyanate groups. Thise fact was important point for the passed impact test. From these results we should be concluded that, the formation films from the formula $\mathrm{E}_{3^{-}}$ $\mathrm{E}_{7}$ were valied for protection of carbon steel surfaces of petroleum and industries equipment. Where the formation of poly(urethane amide) epoxy films were compacted, cmpitability and have elastisity character and high adhesion forcess with the surface of specimens. These fact data were indicated on the validity of the formation films. From these observation results we should be concluded and recommended that the formula $E_{3}-E_{7}$ to protect the surfaces of equipment.

3.5.3 Pinhole( Holiday) data. The Pinhole( Holiday) data were detected for the formation dry films from the formula $E_{1}-E_{7}$ was given in Table (6). The formation dry films from $E_{1}-E_{2}$ were detected some pinhols (failure). While the formation dry films from formula $E_{3}-E_{7}$ were not detected any pinhols (passed) and valied to protection of carbon steel surfaces of equipment. From these results, we should be concluded that, the AEAEPHA copmpound was played a very important rule for improvement the physical and mecanical proparties of painting materials.

3.5.4 Bending data. The bending data for the formed dry films from formula $E_{1}-E_{7}$ was given in Table (6). The data were showed that, the bending data of formed dry films from $E_{1}$ and $E_{2}$ were cracked (failure), while the formed dry films from $E_{3}-E_{7}$ were not affected (passed). From these results, we were observed that, the obtained dry films depended on the chemical structure of the resin and the filler/pigment additives.

\subsection{Chemical properties}

3.6.1Effect of mixture of benzene, toluene and xylene. The effect of texture morphology of the formed dry films of formula $\mathrm{E}_{1}-\mathrm{E}_{7}$, were given in Table (8). These data were inspected after immersed in organic solvents. These were observed that the formation poly (urethane amide) epoxy films of $E_{1}$ was partially swelled after 24 days, while the formed films from formula $\mathrm{E}_{2}$ was partially swelled at 48 days, on the other hand the formed films from formula $E_{3}-E_{7}$ were not effected by organic solvent untile 72 days. That is due to the formation of closed and stable films of poly (urethane amide) epoxy, which were confirmed also by the 
interaction of some hydroxyl groups of the Al-silicat with some cyano groups of TDI. And also indicated on the compatibility of the binder with the inorganic filler / pigments and complete reacted with curing agent TDI. So that, we should be concluded that the formed of dry poly (urethane amide) epoxy films from formula $E_{3}-E_{7}$ were valied to applied as corrosion protection coating of equipment in petroleum media.

$6^{\text {th }}$ INTRERNATIONAL CONFERENCE ON CHEMICAL AND ENVIROMENTAL ENGINEERING (ICEE)

3.6.2 Effect of methyl ethyl ketone (MEK) and chloroform on the formed dry poly (urethane amide) epoxy films according to ASTM (D-4752-59). The formed dry films were not affected by the rubbing of the formed dry films by MEK and chloroform, respectivly, for 50 times. These results were indicated on the stability of $\mathrm{Zn}$, adhesion and compatibility with the formed dry poly (urethane amide) epoxy films.

3.6.3 Evaluation the effect of aggrisives media on the formed dry poly (urethane amide) epoxy films. Effect of $10 \% \mathrm{H}_{2} \mathrm{SO}_{4}$ on the formed dry poly (urethane amide) epoxy films on the surface of specimens. Table (9) illusterate the data of the effect $10 \% \mathrm{H}_{2} \mathrm{SO}_{4}$ on the texture surface of the formed films from formula $\mathrm{E}_{1}-\mathrm{E}_{7}$. From the obtained data we were observed that the corrosion spots were appeared at 30 days for $E_{1} \& 50$ days for $E_{2}$, while the dry films formed from formula $E_{3}-E_{7}$, the few corrosion spots were appeared on the surface of formed films. The ratio of spots respect to the total surface area were less than $0.1 \%$ (rust grade $8 \mathrm{~B}$ ASTM D-610), these spots should be neglected. So that we were concluded that the formed dry films from formula $\mathrm{E}_{3}-\mathrm{E}_{7}$ were valid to protect the surface of equipment against aggressive acidic media. These results were illusterated that the compound AEAEPHE compound played avery important rule in the painting materials for protection the surface of equipment.

3.6.4 Effect of the synthetic $(3.5 \% \mathrm{NaCl})$ sea water on the formed dry films on the surface of specimens. Tables (10) illusterate the data of the effect $(3.5 \% \mathrm{NaCl})$ synthetic sea water on the surface of the formed films from formula $E_{1}-E_{7}$. The obtained data we were observed that the lettle corrosion spots were appeared at 48 days for formed film of $E_{1} \& E_{2}$, while the dry films formed from formula $\mathrm{E}_{3}-\mathrm{E}_{7}$, the corrosion spots were not appeared on the surface of formed films untile 72 days.

So that one should be concluded that the formed dry films from formula $E_{3}-E_{7}$ were valid to protect the surface of equipment against aggressive sea water media. These results were illusterated that the AEAEPHA , epoxy, inorganic filler/ pigments compounds played important rule in the painting materials for protection the surface of equipment.

Table:8 Visual inspection of the effect of the organic solvent (Toluene, Benzene, Xylene) on the dry films formed from formula $E_{1}-E_{7}$

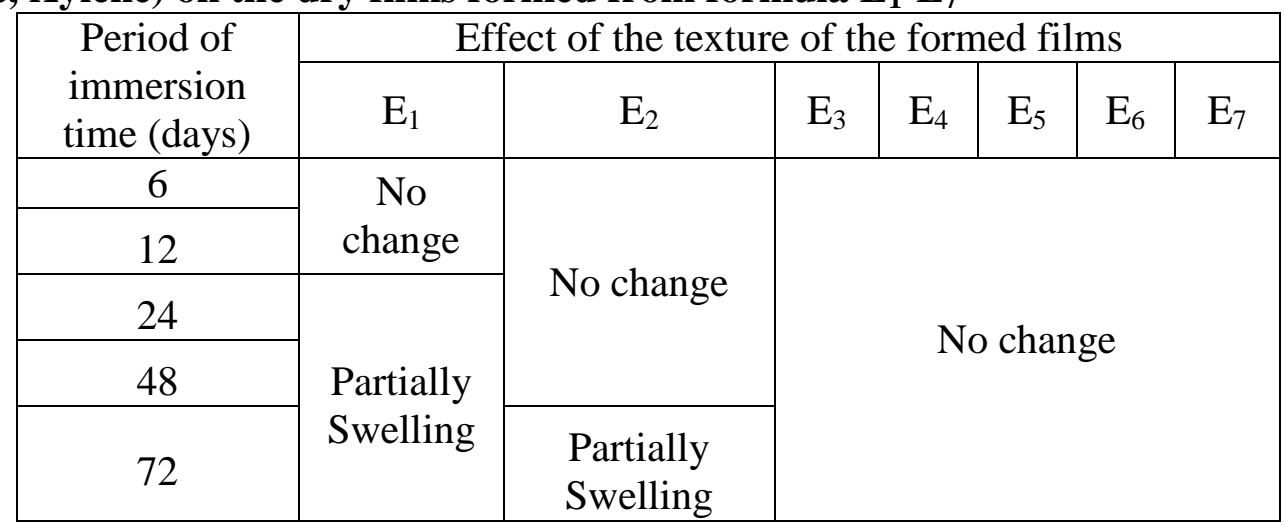


Table-9 Data of corrosion tests of the dry films formed from formula $E_{1}-E_{7}$ on the specimens surface in $10 \% \mathrm{H}_{2} \mathrm{SO}_{4}$ for 50 days.

\begin{tabular}{|c|c|c|c|c|c|c|}
\hline \multirow{2}{*}{$\begin{array}{l}\text { Period of immersion time } \\
(\mathrm{hr})\end{array}$} & \multicolumn{6}{|c|}{ Visual inspection for the dry films formed in $10 \% \mathrm{H}_{2} \mathrm{SO}_{4}$} \\
\hline & $\mathrm{E}_{1}$ & $\mathrm{E}_{2}$ & $E_{3}$ & $E_{4}$ & $\mathrm{E}_{5}$ & \begin{tabular}{l|l}
$\mathrm{E}_{6}$ & $\mathrm{E}_{7}$ \\
\end{tabular} \\
\hline 10 & $\begin{array}{c}\text { No } \\
\text { change }\end{array}$ & \multirow{2}{*}{\multicolumn{4}{|c|}{$\begin{array}{c}\text { No } \\
\text { Change }\end{array}$}} & \multirow{5}{*}{$\begin{array}{c}\text { No } \\
\text { Change }\end{array}$} \\
\hline 20 & $\begin{array}{c}\text { No } \\
\text { change }\end{array}$ & & & & & \\
\hline 30 & $\begin{array}{c}\text { No } \\
\text { change }\end{array}$ & $\begin{array}{c}\text { No } \\
\text { change }\end{array}$ & $\begin{array}{c}\text { No } \\
\text { change }\end{array}$ & $\begin{array}{c}\text { No } \\
\text { change }\end{array}$ & $\begin{array}{c}\text { No } \\
\text { Change }\end{array}$ & \\
\hline 40 & $\begin{array}{c}9 \text { spots } \\
\text { Appeared }\end{array}$ & $\begin{array}{c}\text { No } \\
\text { change }\end{array}$ & $\begin{array}{c}\text { No } \\
\text { change }\end{array}$ & $\begin{array}{c}\text { No } \\
\text { change }\end{array}$ & $\begin{array}{c}\text { No } \\
\text { Change }\end{array}$ & \\
\hline 50 & $\begin{array}{c}19 \text { spots } \\
\text { Appeared }\end{array}$ & $\begin{array}{l}10 \text { spots } \\
\text { appeared }\end{array}$ & $\begin{array}{c}3 \text { spots } \\
\text { appeared }\end{array}$ & $\begin{array}{c}3 \text { spots } \\
\text { appeared }\end{array}$ & $\begin{array}{c}1 \text { spots } \\
\text { Appeared }\end{array}$ & \\
\hline
\end{tabular}

Table-10 Data of corrosion tests of the dry films formed from formula $E_{1}-E_{7}$ on the specimens in sea water for 72 days.

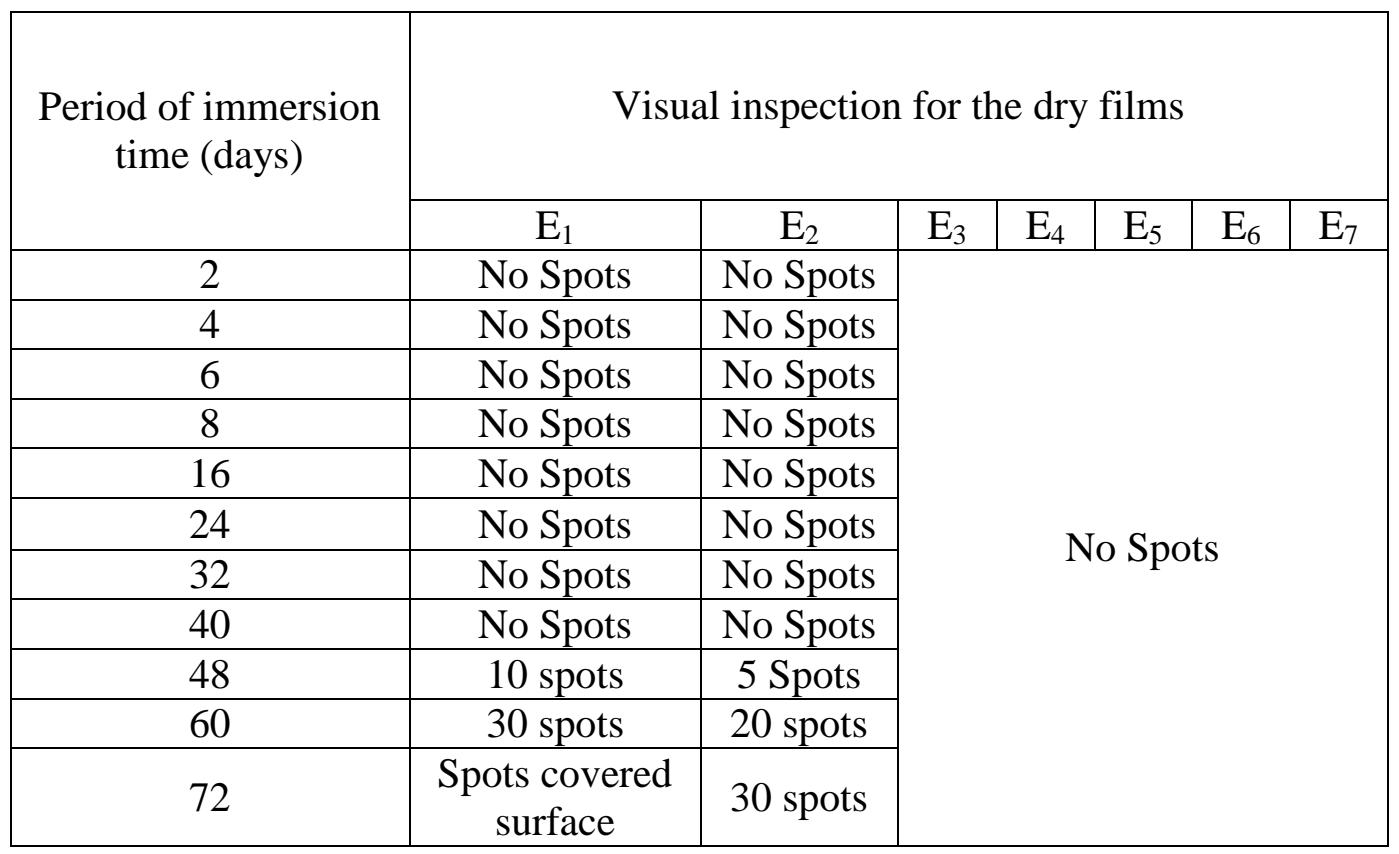

\subsection{Mechanism}

The AEAEPHA compound was reaction with toluene di-isocyant and epoxy resin to formation of poly(urethane amide) epoxy films. Where the AEAEPHA compound was contained on the five hydroxyl groups three amino groups and one amide \& vinyl groups. Where the hydroxy groups were reacted with cyano groups of TDI to formed a polyurethane, and the amino groups were reacted with epoxy oxirine groups to form a poly epoxy amide bonds so that, the AEAEPHA compound were cabaple of formed a polyurethane amide epoxy films. Also some traces of hydroxyl group on the surface of Al silicate and minor of its on the surface of metal were reacted with some cyano groups of TDI to formed urethane bonds. these bonds were able to formed a strong bonds chemically between the surface of specimens and formed films. And also the formation of poly(urethane amide) epoxy films 
have inorganic filler/pigment materilas, $\mathrm{TiO}_{2}, \mathrm{CaCO}_{3}, \mathrm{ZnO}_{2}$ and $\mathrm{Al}$ silicate, which have high stablity and protection phenomena, and these materials were closed any porous in formation films, although the poly(urethane amide) epoxy films were closde surfacce. According to thise mechanisme the formation of poly(urethane amide) epoxy films from formula $E_{3}-E_{7}$ compound have high qualified properties to applied on the surface of petroleum, petrochemical \& other industries equipment.

Generally, the L- ascorbic acid, inorganic filler/pigments compound were environment frindally, egyptian prodducts, have high protection properties and low costes, as well as the raw materials, so that recommended that industries of this painting material should be industried in mass production at egypt.

\section{Conclusions}

- Synthesis of AEAEPHA compound and illustrated by FT-IR, HNMR spectroscopy and elemental analysis

- Formation of painting formula $\mathrm{E}_{1}-\mathrm{E}_{7}$ by blended of AEAEPHA, epoxy, $\mathrm{CaCO}_{3}, \mathrm{TiO}_{2}, \mathrm{Talc}$, $\mathrm{Zn}$ dust and $\mathrm{Al}$ silicate compounds

- Applied These formulation after mixed with TDI on the preparation surface of mild steel specimens

- Studied the optimum condition of curing agent for formed the dry film.

- The dry poly (urethane amide) epoxy films obtained on the surface of specimens

- The formed dry poly (urethane amide) epoxy film have excellent physical, mechanical and chemical properties.

- Finally recommended that the poly (urethane amide) composites material from L-Ascorbic acid industried in many production and applied on the surface of petroleum and industries equibment as protective materials and production in mas scal.

\section{References}

[1] O. M. Abo-Elenien, Synthesizes And Performance of Poly (Ethylene Glycol Terphthalate Dimethyl Siloxane) Compound As Protective Material For Carbon Steel Alloy of Petroleum Pipelines; Chemical technology, an Indian journal Vol. 1, Issue 24 (2006)

[2] O. M. Abo-Elenien, N. O. Shaker and R. M. Mansour, Modification and Characterization Of Natural Oil As Coating Material For Carbon Steel Alloys, Mansoura Journal of Chemistry Vol. 33(2), December, (2006) (51- 68).

[3] O. M. Abo- Elenien, and H. M. Abu-Alainin, Tikrit Journal of Pure Science Vol. 11 No.(1) (2006) 201-206

[4] Abo-Elenien ,O.M. and H.M. Abu-Elainin Tetrapropoxy-silane Blend with Polyisoprene Waste and Zinc Powder for Protection of Petroleum Pipelines. Egypt. J. Petrol., 9(2000)1-13

[5] O. M. Abo-Elenien, R. Mansour; N. M.Amer and Usama, F. M. Kandil, Performance of Synthesised New Bis(p-hydroxyl Phenyl amide) Octane Compound as cmposites painting materials for protection of petroleum mild steel; The $14^{\text {th }}$ International Conference on Petroleum, Minerals Resources \& Development, 9-11 March(2011), Cairo Egypt 
[6] Baifu Xin, Peng Wang, Dandan Ding, Jia Liu, Zhiyu Ren,Honggang Fu; Effect of surface species on $\mathrm{Cu}-\mathrm{TiO} 2$ photocatalytic activity; Applied Surface Science 254(2008)2569-2574.

[7] A. Cackovich and D. Perry, Performance Enhancing Polysiloxanes in UV Coating" , Surf. Coat. Int., 10 (2000) 495.

[8] D. B. Macqueen and Y.D. Blum, Modification of Hydro-siloxane Polymers for Coating Applications, Surf. Coat. Int..,84 (B1) (2001)27.

[9] U.F. Kandil, Nahed M. Amer, Nevien O. Shaker, O. M. Abo-Elenien, Studies the Effect of Some Inorganic Additives on the Efficiency of the Painting Material for Protective the Petroleum Equipment Macromolecules" An Indian Journal, Vol. 5, Issue 12(2009).

[10] William Tao, Hongyang Zhou, Yan Zhang, Gang Li,Novel Silsesquioxane Mixturemodified High elongation Polyurethane with Reduced Platelet Adhesion, Applied Surface Science 254(2008) 2831-2836

[12] H. Ashassi-Sorkhabi, M.R. Majidi; K.Seyyedi, The Corrosion Study of $\mathrm{ZrO}_{2}$ Coatings on Metals Applied Surface Science, 225(2004) 176.

[13] E. O. El-Azabwy, Assessment of Protective Films Based on Polyalkyleneglycol Siloxane on Carbon Steel Alloy, Ms C. Thesis, Al-Azhar University, Faculty of Science for Girls(2002).

[14] N.O.Shaker, A.A.El-Sadawy ,O.M.Abo-Elenien, Protection of Petroleum Equipments By Blending of Friendly Environmental Resins and Pigments" Chemical technology, an Indian journal Vol. 3 Issue 1(2008).

[15] N. Uyanik, H. Yalcinkaya and N. Kizilcan, Poly(dimethyl- siloxane) Containing FiveBlok Copolymar : Effects of Resin Bloks".Surf. Coat. Inte. Part B : Coatings Transactions, 84 (B4) (2001)243.

[16] M. Alagar, M., I. Bilal and V. Mohan, Silicate Esters with Additives as Temporary Protectives on Steel Surfaces, Br. Corros. J. 34 (1) (1999) 75.

[17] H. Zeh, The Determination of VOC Emissions Rrom Latex Paints During and After Application Methods Performance and Precision, Surf. Coat. Int. 3, (2000) 111. 


\section{الملخص العربي}

تخليق وتوصيف عديد (اليوريثان - أميد) الجديد المركب من L - حامض الأسكوربيك كمواد وقائية للمعدات البترولية المئية

$$
\text { أسامة محمود أبو العنين * وخالد محمد زهدى*** }
$$

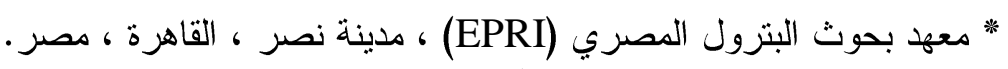

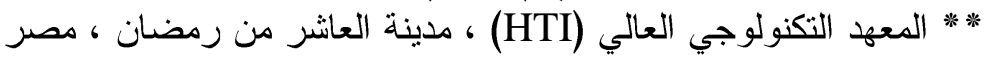

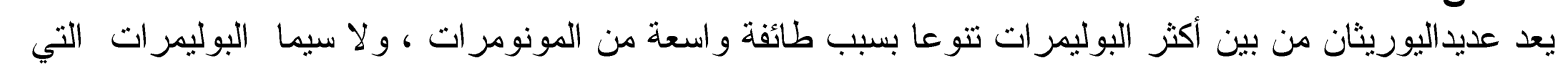

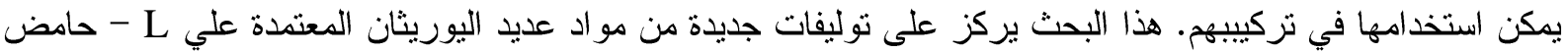

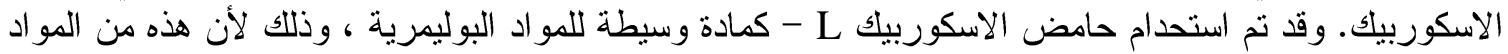

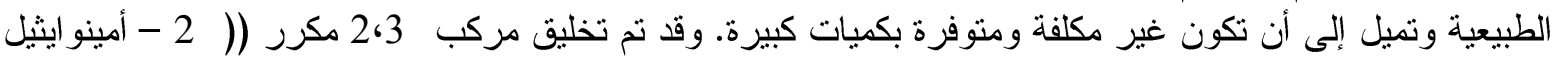

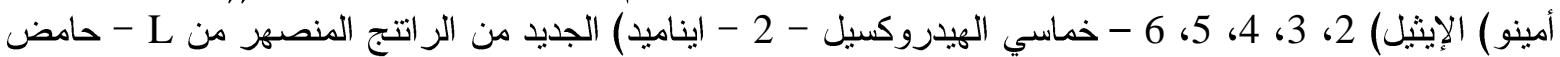

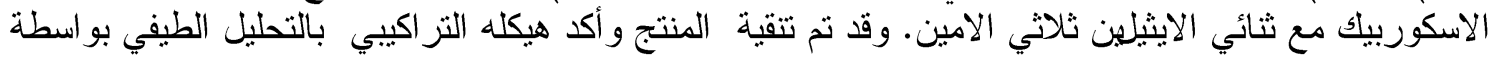

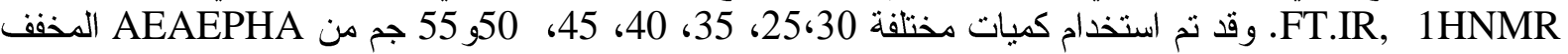

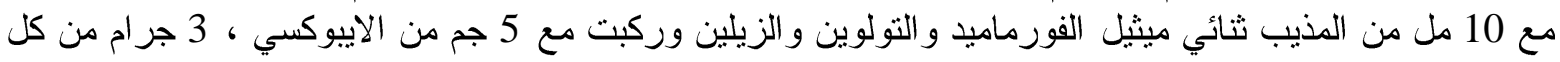
كيات

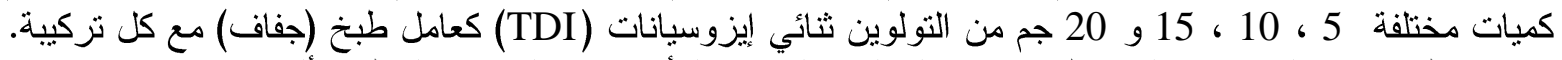

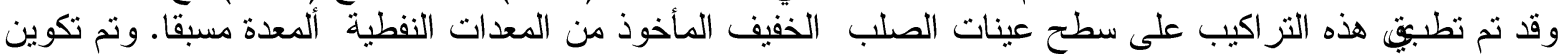

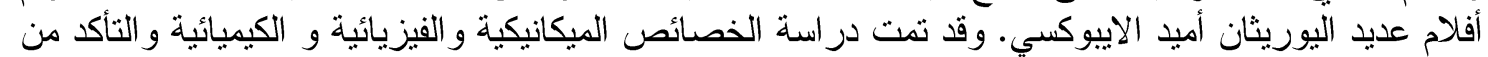

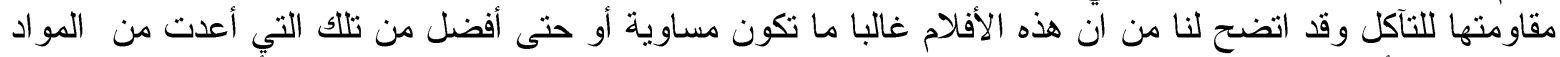

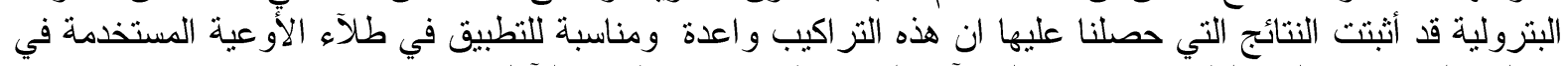
مختلف الصناعات البترولية وغير ها من المنشآت الصناعية كمادة و اقية من التآكل.

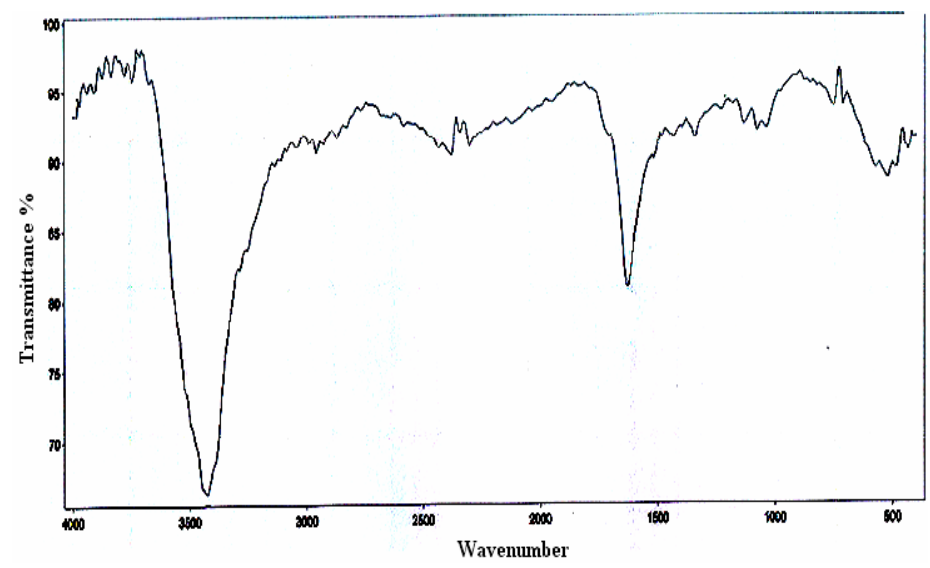

Fig. (1): FT-IR diagram for AEAEPHA compound 


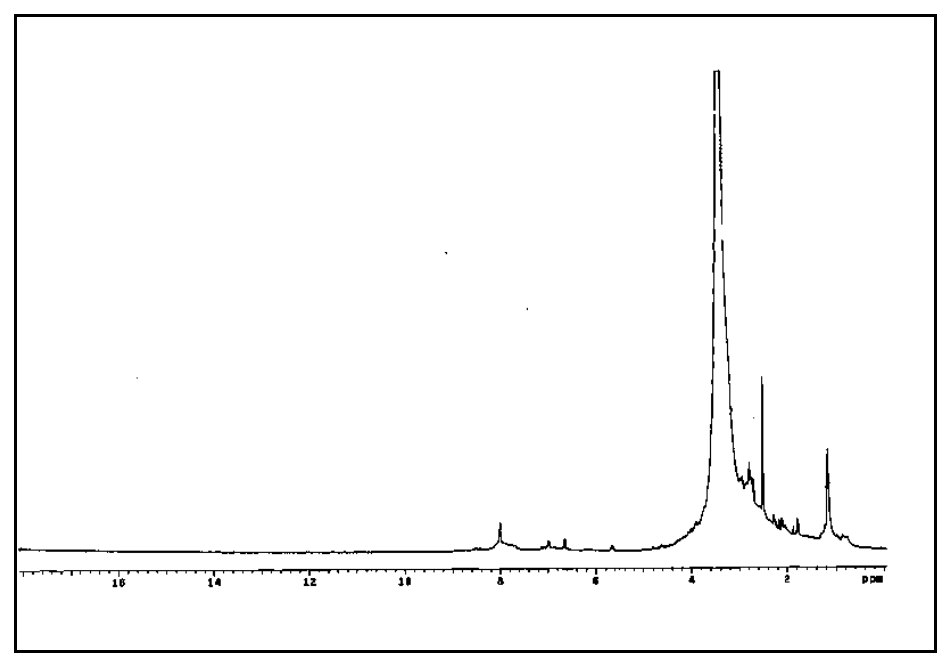

Fig. (2): ${ }^{1}$ HNMR diagram for AEAEPHA compound 